Mediterranean Aquaculture Journal 2015 (7); 12-21.

\author{
Original Article
}

\title{
Growth Performance and Feed Utilization of Hybrid Red Tilapia, Oreochromis niloticus (Linnaeus) X Oreochromis mosambicus (Peters) Fed Different Dietary Protein and Energy Levels under Rearing in Seawater Conditions
}

\author{
El-Dakar ${ }^{1}$ A.Y.; S.M.A. Shalaby ${ }^{1}$ and A.I. Abd Elmonem ${ }^{2}$ \\ 1- Aquaculture Department, Faculty of Fisheries Sciences, Suez University, Suez. Egypt. \\ 2- Faulty of Agriculture, Alexandria University, El-shatby Alexandria, Egypt.
}

\begin{abstract}
A $3 \times 2$ factorial design of three dietary protein levels $(25,30$ and 35\%) and two levels of energy (18 and $20 \mathrm{MJ} / \mathrm{kg}$ ) in three replications was conducted to investigate the proper dietary protein and energy levels for the growth of hybrid red tilapia, Oreochromis nilotics X Oreochromis mosambicus. Eighteen net cages (100 X 40 X $100 \mathrm{~cm}, \mathrm{~L} \mathrm{X} \mathrm{W} \mathrm{X} \mathrm{H)} \mathrm{were}$ stocked with 10 fry of fish weighing $0.4 \mathrm{~g} /$ fish and fed to 16-weeks. No significantly differences $(\mathrm{P}>0.05)$ in final body weight, gain and specific growth rate were observed among fish fed diet containing different energy levels. However, at the dietary protein level of 25 and $30 \%$, growth performance parameters were improved as dietary energy level increased from 18 to $20 \mathrm{MJ} / \mathrm{kg}$. The improvement of growth, feed conversion, nutrient efficiency utilization were achieved with the diet containing $30 \%$ protein and $20 \mathrm{MJ} / \mathrm{kg}$ diet corresponding to $\mathrm{P} / \mathrm{E}$ ratio of $15 \mathrm{~g} / \mathrm{kJ}$. Moisture and lipid contents were affected by dietary protein levels not by energy levels. Fish protein content tended to increase as protein level increased in the tested diets.
\end{abstract}

Key words: red tilapia, seawater, protein, energy, protein sparing effect

Received: 2 May 2014

Accepted: 9 July 2014

Corresponding author:

Ashraf Y. El-Dakar

Aquaculture Department,

Faculty of Fisheries Sciences, Suez University,

Suez, Egypt.

e-mail:ayegypt99@gmail.com

Copyright : All rights reserved to Mediterranean International Aquaculture and Environment Society (MAEPS) 


\section{Introduction}

Tilapia culture is one of the fastest growth farming activities with an average annual growth rate of $13.4 \%$ during 19760-2002 (El-Sayed et al., 2005). Tilapias are widely cultured in about 100 countries in tropical and subtropical regions. The world production of farmed tilapia representing about $6 \%$ of total farmed finfish (FAO, 2004). Recently interest has been shown by commercial aquaculture sector to expand tilapia culture in sea and brackish water in Egypt (El-Sayed et al., 2003) and in Southeast Asia as well as South America (Green, 1997). The major reason for this need is that there are a large number of shrimp ponds available, resulting from either failure in shrimp farming or desires to diversify shrimp culture. Tilapias appear to be the most appropriate choice for such a culture system because their efficient to grow and feed efficiency. This interest in seas and brackish water culture is particularly strong in Thailand and Vietnam where shrimp culture is now commonly reduced to one crop per year, leaving the ponds empty for half a year (Yi et al., 2002). Tilapia culture is also attractive to shrimp farmers as a by-product to utilize abundant phytoplankton in either shrimp ponds or their effluents. Red tilapia has been becoming more and more popular in many parts of the world, and there is a great potential to culture this species in brackish water and seawater ponds 9Yi et al., 2002). At the same time results of tilapia-shrimp polyculture systems either in separated tanks or in cages of hapa net in the same culture pond (Bolivar et al., 2003) encouraged us to study the possibility of red tilapia as a marine culture species. Red tilapias were successfully rearing in intensive enclosed shrimp raceways, the reached to the marketable size producing 8 -

\section{Materials and Methods}

Experimental system

The present work was performed at the Mariculture Research Center, Faculty of Environmental Agriculture Sciences,
$25 \mathrm{~kg} / \mathrm{m}^{3}$ productivity under Egyptian conditions (Uupublished data). For the maximization of optimum growth rate and productivity of red tilapia, it is necessary to determine the protein and energy requirements of this fish under mariculture conditions. Since the protein content in finfish diets usually constitutes the largest single cost factor in feeds. The protein requirement of fish varies with fish species, fish size, dietary non-protein energy level and environmental conditions (NRC, 1993). Increasing protein level in diets can lead to improved fish productions (Lee and Kim, 2001). However, excessive dietary protein level is not economical for fish culture because it is responsible for a large part of the feed cost. Dietary protein and energy levels are known to influence the growth and boy composition of fish (Lovell, 1989). Insufficient energy in diets causes protein waste due to the increase of dietary protein proportion used for energy and produced ammonia can reduce the water quality. On the contrary, body lipid deposition and growth reduction were found because of a lack of necessary nutrient for growth (Daniels and Robinson, 1988). Therefore, it is important to improve the dietary protein utilization for body protein synthesis rather than for energy purposes. In addition, the optimization of the ratio to play an important role in protein and energy utilization for fish (Kaushik, 1994). Many authors have studied protein and energy requirements for tilapia species that reared in freshwater and brackish water, but they are scarce for red tilapia reared in seawater. Therefore, the current study was conducted to evaluate the effect of dietary protein at two energy (lipid) levels on the growth, feed and nutrient utilization and body composition of red tilapia reared in seawater.

Suez Canal University. El-Arish, NorthSinai, Egypt Experimental fish were obtained from Marine Hatchery k-21, Alexandria, Egypt. Fish were transported in polyethylene bags field with 3:1 oxygen: 
seawater, respectively. At arrival fish were released in rectangular fiberglass tank filled with seawater. Fish were quarantined for one week in the rearing tank, and then sorted by weight removing all large and small individuals. The feeding trial was carried out in eighteen net cages $(100 \times 40$ X $100 \mathrm{~cm}$; L X W X H) placed in two large fiberglass tanks using three replicate cages per treatment. Ten fry fish (average weight $0.4 \mathrm{~g} /$ fish) were randomly stocked into each experimental cage. During the first three days of the experiment, dead fish were replaced with individuals of the same size. Approximately $35 \%$ of the water was exchanged daily and aeration was provided using submerged air diffusers and a reciprocating air blower. Salinity, temperature, $\mathrm{pH}$, dissolved oxygen and photoperiod were measured daily and remained at approximately $35 \mathrm{ppt}, 28{ }^{\circ} \mathrm{C}$, 8.6, $7 \mathrm{ppm}$ and 12:12 L.D., respectively.

\section{Diet preparation and feeding}

Experimental diets were prepared on site using locally available ingredients (Table 1). Ingredients were thoroughly mixed, then boiling water added to the mixture. The mash was palletized using a meat mincer with a $1.5-\mathrm{mm}$ die. Pellets were dried at $40{ }^{\circ} \mathrm{C}$ in an oven and stored at -20 ${ }^{\circ} \mathrm{C}$. A $3 \times 2$ factorial design using three replicates per treatment combination of dietary protein and energy levels was conducted to investigate the proper dietary protein and energy levels for the growth of hybrid red tilapia. Oreochromis niloticus X Oreochromis mosambicus. Six tested diets were formulated to contain three levels of protein (25. 30 and 35\%) and two levels of energy (18 and $20 \mathrm{MJ} / \mathrm{kg}$ ). Fishmeal was used, the primary protein source and dietary protein level increased in proportion to its percentage, oil mixture of sunflower and soybean $(1: 1 \mathrm{w} / \mathrm{w})$ was added as 0 and $5 \%$ of diet at each protein level. Fishmeal was home made by collecting small fish and non-sealed fish named locally "Wazafa" from fish market to dry in oven at $60 \mathrm{C}$ to dryness. Then dry fish were grounded and sieved prior to keep at -20C until use, while the rest ingredients were obtained, from local markets. Ingredients and chemical compositions of the experimental diets are resented in table (1). Each diet was offered to three randomly chosen cages, six days a week for 112 days. Fish were fed $8,6,5,3 \%$ of the body weight daily for 1-4, 5-6, 7-8 and 9-16 week, respectively. Daily ration was divided into three equal portions supplied at 0900, 1200 and 1500 hrs. Fish in each cage were weighed at two-week intervals and ration adjusted according to new fish weight.

\section{Sample collection and analysis}

Fish and feed samples were taken of the beginning of the experiment and stored at $2^{\circ} \mathrm{C}$ pending composition analysis. At the end of the experiment, all fish in each cage were killed pooled and stored $-2^{\circ} \mathrm{C}$ for subsequent proximate analysis. Chemical analysis of feed and fish were performed according to methods described by AOAC (1993). Gross energy content of the experimental diets and fish samples were calculated by using factors of 23.4, 39.2 and $17.2 \mathrm{MJ} / \mathrm{g}$ for protein, lipid and carbohydrate, respectively (Cho et al., 1982). Specific growth rate (SGR), feed conversion ratio (FCR), protein efficiency ratio (PER), apparent protein utilization (APU), energy retention (ER), daily feed intake (DFI), daily energy intake (DEI), daily protein intake (DPI) were calculated as:

SGR $=100 \mathrm{X}($ In FBW - in IBW $) / \mathrm{t}$

Where FBW is final body weight $(\mathrm{g})$, IBW is initial body weight $(\mathrm{g})$ and $\mathrm{t}$ is fed days.

DFI $=$ dry matter intake X $100 /(\mathrm{IBW}+$ FBW + dead fish weight) $X t / 2$ ).

$\mathrm{DEI}=$ energy intake $\mathrm{X} 100(1 \mathrm{BW}+\mathrm{FBW}$ + dead fish weight $X t / 2$ )

FCR $=$ weight of feed offered to fish $(\mathrm{g}) /$ weight gain of fish $(\mathrm{g})$

$\mathrm{PER}=\{$ weight gain $(\mathrm{g}) /$ protein intake (g) $\}$ X 100

$\mathrm{APU}=\{$ protein retained $(\mathrm{g}) /$ protein fed (g) $\} / 100$ 
$\mathrm{ER}=100\{$ energy retained in fish $(\mathrm{MJ}) / \mathrm{energy}$ offered to fish (MJ)\}

\section{Statistical analysis}

All data of the experiment were analyzed using the two-way analysis of variance, fixed-effect model to determine significant differences among treatment means. All statistical analysis was performed according to Steel and Torri (1980) using the SAS software. Differences were subjected to Duncan's Multiple Range-Test.

Table 1. Ingredients and proximate analysis of the experimental diets

\begin{tabular}{|c|c|c|c|c|c|c|}
\hline \multirow[t]{2}{*}{ Item } & \multicolumn{6}{|c|}{ Protein diets } \\
\hline & $25 / 18$ & $25 / 20$ & 30/18 & $30 / 20$ & $35 / 18$ & $35 / 20$ \\
\hline \multicolumn{7}{|l|}{ Ingredients } \\
\hline Fish meal $^{1}$ & 50 & 50 & 150 & 150 & 200 & 200 \\
\hline Soybean meal & 340 & 340 & 340 & 340 & 340 & 340 \\
\hline Yellow corn & 50 & 50 & 50 & 50 & 50 & 50 \\
\hline Wheat milling by-product & 480 & 390 & 340 & 290 & 290 & 260 \\
\hline Wheat bran & 100 & 100 & 100 & 100 & 100 & 100 \\
\hline Sunflower oil & 0 & 25 & 0 & 25 & 0 & 25 \\
\hline Soybean oil & 0 & 25 & 0 & 25 & 0 & 25 \\
\hline Vitamins $^{2}$ & 10 & 10 & 10 & 10 & 10 & 10 \\
\hline Minerals $^{3}$ & 10 & 10 & 10 & 10 & 10 & 10 \\
\hline \multicolumn{7}{|c|}{ Chemical composition proximates (\% on DM basis): } \\
\hline Dry matter(\%) & 90 & 90.05 & 89.98 & 90.25 & 90.36 & 90.28 \\
\hline Crude protein & 25.04 & 25.12 & 30.01 & 30.01 & 35.05 & 35.04 \\
\hline Crude lipid & 6.19 & 15.58 & 6.18 & 15.16 & 6.17 & 15.15 \\
\hline Crude fiber & 2.43 & 2.48 & 2.38 & 2.43 & 2.34 & 2.39 \\
\hline Ash & 9.46 & 8.97 & 10.85 & 10.37 & 12.25 & 11.77 \\
\hline Carbohydrate & 56.88 & 47.85 & 50.58 & 42.03 & 44.19 & 35.64 \\
\hline Gross energy $\left(\mathrm{MJ} / \mathrm{kg}^{-1}\right)$ & 18 & 20 & 18 & 20 & 18 & 20 \\
\hline PE ration $\left(\mathrm{gkJ}^{-1}\right)_{-}$ & 13.86 & 12.42 & 16.54 & 14.86 & 19.24 & 17.29 \\
\hline
\end{tabular}

1) Fishmeal-homemade contained 58.59 and $14.84 \%$ crude protein and lipid, respectively.

2) Vitamin mixture $(\mathrm{g} / 100 \mathrm{~g})$ was $960000 \mathrm{IU}, 160000 \mathrm{IU}, 0.8 \mathrm{~g}, 80 \mathrm{mg}, 0.32 \mathrm{~g}, 0.12 \mathrm{~g}, 0.8 \mathrm{~g}, 0.8 \mathrm{mg}$ $1.6 \mathrm{~g}, 80 \mathrm{mg}, 4 \mathrm{mg}$, 40g. of vitamin A, D3, E, K, B1, B2, B6, Pantothenic acid, B12, Nilacin, Folic acid Biotin, Choline chloride, respectively.

3) Mineral mixture $(\mathrm{g} / 100 \mathrm{~g})$ was $12.75,72.85$,

\section{Results}

Growth performance

The survival rate recorded during the experimental period was $100 \%$ Fish fed $30 \%$ protein exhibited higher body weight, gain and SGR than other tested levels. However, increase protein percentage to $35 \%$ resulted in a decrease of growth and performance (Table 2). The lowest growth rate was found with diets containing $2 \%$ protein. Concerning to the effect of dietary energy level on growth performance of red tilapia reared in seawater shows no significantly differences $(\mathrm{P}>0.05)$ among fish fed diet containing 18 and $20 \mathrm{MJ} / \mathrm{kg}$ diet (Table 2 ). However, at the dietary protein level of $25-30 \%$, growth performance parameters were improved as dietary energy level increased from 18 to 20 $\mathrm{MJ} / \mathrm{kg}$ but at the protein level Table growth, feed and nutrient efficiencies utilization of red tilapia fed different protein and energy levels under seawater conditions. 
Table 2. Growth rate, survival, feed intake, feed conversion ratio and protein efficiency ratio of red tilapia fed different protein and energy levels reared under seawater conditions.

\begin{tabular}{|c|c|c|c|c|c|c|}
\hline Diets & $\begin{array}{l}\text { Weight gain } \\
\text { g/fish }\end{array}$ & $\begin{array}{l}\text { SGR } \\
\text { \%/day }\end{array}$ & $\begin{array}{c}\text { Survival } \\
\%\end{array}$ & TFI & FCR & PER \\
\hline $25 / 18$ & 39.20 & 4.11 & 100 & 80.48 & 1.85 & 2.16 \\
\hline $25 / 20$ & 43.50 & 4.18 & 100 & 73.63 & 1.55 & 2.59 \\
\hline $30 / 18$ & 44.50 & 4.21 & 100 & 95.84 & 1.74 & 1.91 \\
\hline $30 / 20$ & 49.40 & 4.31 & 100 & 88.34 & 1.62 & 2.06 \\
\hline $35 / 18$ & 45.65 & 4.24 & 100 & 82.00 & 1.63 & 1.76 \\
\hline $35 / 20$ & 44.25 & 4.21 & 100 & 81.94 & 1.67 & 1.73 \\
\hline \multicolumn{7}{|c|}{ Analysis of variance, $\mathrm{P}>\mathrm{F}$} \\
\hline Protein & 0.184 & 0.16 & & 0.06 & 0.14 & 0.001 \\
\hline Energy & 0.32 & 0.34 & & 0.26 & 0.21 & 0.11 \\
\hline Interaction & - & - & & - & - & 0.15 \\
\hline PSE & 1.54 & 0.03 & & 2.76 & 0.03 & 0.04 \\
\hline
\end{tabular}

* Values in the same column not sharing superscripts are significantly different $(\mathrm{P}<0.05)$

Table 3. Body composition, protein productive value and energy retention of red tilapia fed different protein and energy levels under seawater conditions.

\begin{tabular}{|l|l|l|l|l|l|l|}
\hline \multicolumn{1}{|c|}{ Diets } & Moisture\% & Protein & Lipid & Ash & APU\% & ER\% \\
\hline Initial fish & 71.89 & 17.18 & 6.52 & 4.40 & - & - \\
\hline $25 / 18$ & 75.1 & 13.73 & 4.67 & 6.41 & 30.9 & 12.31 \\
\hline $25 / 20$ & 74.6 & 14.26 & 5.04 & 6.11 & 36.8 & 13.23 \\
\hline $30 / 18$ & 74.5 & 14.91 & 5.1 & 5.49 & 28.5 & 13.00 \\
\hline $30 / 20$ & 73.4 & 15.87 & 5.6 & 5.11 & 32.7 & 12.63 \\
\hline $35 / 18$ & 73 & 16.45 & 6.08 & 4.5 & 28.9 & 13.93 \\
\hline $35 / 20$ & 72.7 & 16.86 & 6.39 & 4.06 & 29.2 & 12.33 \\
\hline Analysis of variance, $\mathrm{P}>\mathrm{F}$ & 0.04 & 0.02 & 0.03 & 0.008 & 0.04 & 0.18 \\
\hline Protein & - & - & 0.19 & - & 0.18 & - \\
\hline Energy & 0.33 & 0.17 & - & 0.25 & - & - \\
\hline Introduction & 0.27 & 0.2 & 0.12 & 0.11 & 0.70 & 0.32 \\
\hline PSE &
\end{tabular}

*Values in a column not having a common superscript are significantly different

** Pooled standard error.

Of $35 \%$, the differences of weight gain and SGR were not significant $(\mathrm{P}>0.05)$. The greatest final body weight and growth rate was achieved with the diet containing $30 \%$ protein and $18 \mathrm{MJ} / \mathrm{kg}$ diet corresponding to diet contained $\mathrm{P} / \mathrm{E}$ ratio of $15 \mathrm{~kJ} / \mathrm{g}$ protein.

\section{Feed utilization efficiency}

Feed intake were affected by dietary protein level and tended to increases with increasing dietary protein until level of $30 \%$ (Table ). Daily feed intake decreased with increasing dietary energy and protein levels. Feed gain ration was insignificantly $(\mathrm{P}>0.05)$ among all treatments. Protein efficiency ratio was significantly by dietary protein $(\mathrm{P}<0.002)$ and energy $(\mathrm{P}<0.04)$ levels. Both of APU and PER had a negative relationship dietary protein level (Table 3). Energy retention was not affected by dietary protein and energy levels $(\mathrm{P}>0 / 05)$.

\section{Body composition}


Moisture, lipid, protein and energy were affected by dietary protein level but not affected by energy level (table 4). The body moisture, lipid and energy contents tended to increase with increasing protein level from 25 to $35 \%$. Ash content of fish tended to increase significantly $(\mathrm{P}<0.02)$ with increasing protein $(\mathrm{P}<0.0001)$ and energy $(\mathrm{P}<0.002)$ dietary levels.

\section{Discussion}

Tilapia hybrids that have descended from an $O$. mosambicus parent are believed to be highly tolerant to saline waters (Romana-Eguia and Eguis, 1999). Red tilapia were reared in seawater in seawater without adverse effect in survival, growth and feed utilization in the present study. Growth rats of red tilapia fed the diets containing $18 \mathrm{MJ} / \mathrm{kg}$ diet increased with increasing dietary protein level, while this value in fish fed the diets containing $20 \mathrm{MJ} / \mathrm{kg}$ diet increased with increasing dietary protein up to $30 \%$ and then decreased at $35 \%$ protein. The different growth response to protein and energy levels in fish diets is probably due to dietary non-protein energy level (De Silva et al., 1991; Company et al. 1999. McGoogan and Gatilin 1999; Kim and Lee 2005). This indicates that $30 \%$ protein with $20 \mathrm{MJ} / \mathrm{kg}$ diet has excess energy for red tilapia cultured in seawater. Excessive dietary enrgy can lead to reduced growth of fish. Due to lacking of necessary nutrients for growth, resulting also from reduction in feed intake by fish (Daniels and Rebinson, 1986). Higher growth performance of red tilapia within dietary protein level of $30 \%$ and $20 \mathrm{MJ} / \mathrm{kg}$ diet could be explained as this diet provided more energy for metabolization of protein to muscle tissue. On the other hand, fish received a lower energy level $(18 \mathrm{MJ} / \mathrm{kg})$ could be utilizing part of dietary protein as energy source. The protein sparing effect, evident when energy is added to the diet and observed in tilapia species (Shiau and Hang 1989; 1990; De Silva et al., 1991; Shiau and Peng, 1993) and in many fish species (hutchins et al., 1998; Shalaby et al., 2001; Meyer and Fracalossi 2004; Kim and Lee, 2005), was also clearly expressed by red tilapia reared in sea water. Growth of fish fed diet of 25:20 was similar to those fed the $30: 18$ and 35.20 diets. These findings suggest that red tilapia is capable of efficiently utilizing dietary carbohydrates because this was the main non-protein energy source in the tested diets. According to McGoogan and Gatlin (2000), lipids are the main non-protein energy source utilized by fish. However, it is known that comnivorous species such as Nile tilapia, O.niloticus (Ali and Al-Asgah, 2001); Indian carp, Labeo rohita (Jajri, 1995); rabbitifsh, Siganus rivulatus (Shalaby et al., 2001) are able to utilize efficiently carbohydrate as an energy source. Thus, it is important to provide an adequate level and ratio of dietary protein and non-protein energy in order to reduce catabolism of protein for energy. Protein to energy ratio affected on body weight and FCR. The present study indicated that $15 \mathrm{MK} / \mathrm{g}$ was the optimum ratio which achieves the best FCR and growth rate. These results are in agreement of Ross (1982) for Mosambique tilapia and Siddiqui et al. (1998) for Nile tilapia. Feed conversion was improved as increasing of dietary energy levels, however, the differences in FCR among dietary protein were not significant $(\mathrm{P}>0.05)$. Daily feed intake in this study decreased with increasing dietary energy and protein levels agreeing with other species of fish (Kim and Lee, 2005), however, daily energy intake showed no relationship with both tested dietary factors. In contrast, total feed intake increased as dietary protein levels increased an not affected by energy levels due to an increase in dietary protein concentration. These 
results are in agreement with those obtained by Watanabe et al., (2001); Marino et al., (2002), Lee et al., (2002); Meyer and Fracalossi (2004) and Kim and Lee (2005). However, the best way to express feed intake seems to be not in absolute values, such as total feed intake (TF), but in relation to body weight (DFI) because diets which exhibited the highest growth over time, result in higher TFI, but not necessary for DFI (Kin and Lee 2005). The present data suggest that increasing feed intake could be a compensatory way to obtain nutrients in case of fish diets are not adequate (Meyer and Fracalossi (2004). In studies deal with different dietary protein levels, diets which exhibited a higher weight gain and growth usually exhibited at the same time a higher feed conversion efficiency (lower values), as was observed by Shiau and Hung (1980, 1990); Clark et al. (1990); Twibell and Brown (1998). This response was observed for red tilapia reared in seawater, probably because fish weight gain is directly associated to the dietary protein content and also because protein is the preferential energy source in fish metabolic routes. Protein utilization parameters (PER and APU\%) decreased with increasing dietary protein level (Jauncey 1982; Siddiqui et al., 1988). The present work confirmed the above finding. However, PER and APU elevated with increasing dietary energy content and they tended to decrease with high energy diets at all protein levels. These results showed protein sparing effect of lipid for red tilapia reared in seawater. At protein levels of 25 and $30 \%$, increasing dietary energy level from 18 to $20 \mathrm{MJ} / \mathrm{kg}$ diet improved growth rate, feed intake, protein intake and PER. These results are in partial accordance with those reported with tilapia freshwater species by Shiau and
Huang (1989, 1990); De Silva et al. (1991); Shiau and Peng, (1993) and Wafa (2002).

Moisture and lipid contents were affected by dietary protein levels not by energy levels. Fish protein content tended to increase as protein level increase in the tested diets in the present study. In contrast, body fat decreased as dietary protein level increased showing agreement with findings of Shiau and Huang (1989; 1990); De Silva et al., (1991) and Shiau and Peng. (1993) and Wafa (2002) for Nile tilapia. Body protein go adversely fat content of fish fed graded levels of protein (Al-Hafeda 1999; Siddiqui et al., 1988; Kin et al. 2001; Ng. Soon and Hashim 2001; Meyer and Fracalossi, 2004). Buckly and Green (1979) reported that body lipid increased and moisture content decreased as dietary energy increased. Similar results were obtained by Shiau and Huang (1990) with Nile tilapia reared in seawater and by El-Dhhar and Lovell (1995), for tilapia Mozambique. Ash content of fish increased with increasing dietary levels of protein due to increase fish meal percentage in diets containing higher protein levels.

\section{Conclusion}

The results of this study indicate that the diet containing $30 \%$ protein and 18 $\mathrm{MJ} / \mathrm{kg}$ diet energy levels is optimal for growth and effective protein utilization of red tilapia reared in seawater.

\section{Acknowledgment}

This study was financed by the Regional Council for Agricultural Research and Extension (RCARE). Ministry of Agriculture, Egypt. Special thanks to Dr. S.J. Kaushik, Fish Nutrition Laboratory, Unite Mixte INRA-IFREMER, France for reading and corrections the manuscript. 


\section{References}

Al-Hafeda, Y.S. 1999, Effect of dietary protein on growth and body composition of Nile tilapia Oreochromis niloticus, Aquaculture Research 30. 385-393.

Ali, A. and Al-Asgah, N.A. 2001. Effect of feeding different carbohydrate to lipid ratios on growth performance and body composition of Nile tilapia (Oreochromis niloticus) fingerlings. Animal Research 50, 91-100.

AOAC,1993 .(Association of Official Analytical Chemists). Official Methods Analysis of 16 th Edn. AOAC. Arlington, Virginia, USA.

Bolivar,R.;Contreras,W.;Ti,Y.andFitzsim mons, K. 2003. Environmental and economic impacts of tilapia and shrimp polycultures. Proceedings abstract of the Conference of Aquaculture America 2003 (New Frontiers in Aquaculture). Webster C.D. (ed.) World Aquaculture Society. Pp: 91.

Buckly, J.T. and Green, T.D.D. 1979. Influence of feed on body composition of finfish In: J.E. Halver and K. Tiews (1978). Fish Feed Technoogy. II, 334343.

Cho, C.Y.; Slinger, S.J. and Bayley, H.S. 1982. Bioenergetics of salmonid fishes: energy intake expenditure and productivity.Comparative Biochemistry and Physiology 73B, 25-41.

Clark, A.E.;Watanabe, W.O.; Olla, B.L.and Wickuind, E.I. 1990. Growth feed conversion and protein utilization of Florida red tilapia fed isocaloric diets with different protein levels in seawater pools, Aquaculture 88: 75-85.

Company,R.;Calduch-

Giner,J.A.;Kaushik,S.andPerezSanchez J. 1999. Growth performance and adiposity in gilthead seabream (Sparus aurata); risks and benefits of high energy diets Aquaculture 171, 279-292.

Daniels, W.H. and Rebinson, E.H. 1986. Protein and energy requirements of juvenile red drum (Sciaenops ocellatus). Aquaculture 53, 243-252.

De Silva, S.S.;Gunasekera,R.M. and Shim, K.F.1991. Interactions of varying dietary protein and lipid levels in young red tilapia; evidence of protein sparing. Aquaculture 95, 305-318.

El-Dahhar, A.A. and Lovell, R.T. 1995. Effect of protein to energy ration in purified diets on growth performance and feed utilization of Mssambique tilapia (Oreochromis mossambicus). Aquaculture Research 26, 451-457.

El-Sayed, A.M.; Mansour, C.R. and Ezzat, A.A. 2003. Effect of dietary protein level on spawning performance of Nile tilapia (Oreochromis niloticus) broodstock reared at different water salinities. Aquaculture 220, 619-632.

El-Sayed, A.M.; Mansour, C.R. and Ezzat, A.A. 2005. Effect of dietary lipid source on spawning performance of Nile tilapia (Oreochromis niloticus) broodstock reared at different water salinities. Aquaculture 248, 187-196.

FAO, 2004.Food and Agriculture Organization of the United Nations. FAO Fish Stat plus. Aquaculture Production 1970-2002 Rome, Italy.

Green, B.W. 1997. Inclusion of tilapia as a diversification strategy for Penaeid shrimp culture. In: D.E. Alston, B.W. Green and H.C. Clifford (Editors). IV Symposium on Aquaculture in Central America Tegucigalpa, Honduras, pp. 85-93.

Hutchins, C.G.;Rawles,S.D. and Gatlin, D.M.1998. Effects of dietary carbohydrate kind and levels on growth, body composition and glycemic response of juvenile sunshine bass (Morone chrysops \& female $\mathrm{X}$ Morone saxatilis \& male). Aquaculture 161, 187-199.

Jauncey, K. 1982. The effect of varying dietary protein level on growth, food conversion, protein utilization and body composition of juvenile tilapia (Sarotherodon mossambicus). Aquaculture 27, 43-54. 
Kaushik, S.J. 1994. Nutritional strategies for the reduction of requirements wastes. Proceedings of FOID "94 THE Third International Conference on Fisheries and Ocean Industrial Development for Productivity Enhancement of the Coastal Waters. Pusa, Korea, 115-132.

Kim, K.W.; Wang, W.J. and Bai, S.C. 2001. Reevaluation of the optimum dietary protein level for the maximum growth of juvenile Korean rockfish (Sebastes schiegeli Hilgendorf). Aquaculture Research 32, 119-125.

Kim, L.O. and Lee, S.M. 2005. Effect of dietary protein and lipid levels on growth and body composition of of bagrid catfish (Pseudobagrus fulvidraco). Aquaculture 243, 323-329.

Lee, S.M. and Kim, K.D. 2001. Effect of dietary protein and energy levels on the growth protein utilization and body composition of juvenile masu salmon (Oncorthynchus masou Brevoort), Aquaculture Research 32, 39-45.

Lee, S.M.;Kim,D. and Cho, S.H. 2002. Effects of dietary protein and lipid level on growth and body composition of juvenile ayu (Plecoglossus altivellis) reared in seawater. Aquaculture Nutrition 8, 53-58.

Lovell, R.T. 1989. Nutrition and feeding of fish Van Nostrand Reinhold, New York, Ny 260 pp.

Martino, R.C.; Cyrino, J.E.P. Portz, L. and Trugo, L.C. 2002. Effect of dietary lipid level on nutritional performance of the surubim (Psiudoplystoma coruscans). Aquaculture 209, 209-218.

McGoogan, B.B. and GatlinIII, D.M. 1999. Dietary manipulation affecting growth and nitrogenous waste production of red drum (Sciaenops ocellatus): I, Effects of dietary protein and energy levels. Aquaculture 178, 333-348.

Meyer, G. and Fracalossi, D.M.2004. Protein requirement of Jundia (Rhamdia quelen) at two dietary energy concentrations. Aquaculture 240-331343.

Ng,W.K.; Soon, S.C. and Hashim,R. 2001. The dietary protein requirement of a bagrid catfish (Mystunemrus Cuvier and Vakenciennes), determined ung ung semipurified diets of varying protein level. Aquaculture Nutrition 7, 45-51.

NRC (National Research Council) 1993, Nutrition requirements of fish National Academy Press Washington, D.C. 114 pp.

Romana-Eguia, M.R. and Eguia, R.V. 1999. Growth of five Asian red tilapia strains in saline environments. Aquaculture 173, 161-170.

Roos, B. 1982. Protein requirement of sub-adult Sarothoerodon mossambicus. In: k. Jauncey and B. Ross (ed.) pp.11 (Review) a guide to tilapia feeds and feeding. Institute of Aquaculture Stirling University.

Shalaby,S.M.;El-Dakar,A.Y.andGhoneim, S.I. 2001. Protein sparing sparing effect by carbohydrate in diets of rabbitfish, Siganus rivulatus. Egyptian Journal of the Aquatic Biology and Fisheries 5, 87-98.

Shiau, S.Y. and Hung, S.L. 1990. Influence if varying energy levels with to protein concentration in diets for hybrid tilapia (Oreochromis niloticus X $O$. aureus) reared in seawater Aquaculture 91, 143-152.

Shiau, S.Y. and Hung, S.L. 1989. Optical dietary protein level for hybrid tilapia (O. niloticus $\mathrm{X} O$. aureus) reared in seawater. Aquaculture 81, 119-127.

Shiau, S.Y. and Peng, P.Y. 1993. Protein sparing effect of carbohdydrates in diets for Tilapia, Orechromis nilotica X O. oureus. Aquaculture, 117, 327-334.

Siddiqui,A.Q.;Howlader,M.S.andAdam,A. A. 1990. Effect of dietary protein on growth, feed conversion and protein utilization in fry and youg Nile tilapia. Orechromis niloticus. Aquaculture, 70, 63-73. 
Steel, R.G. and Torri, J.H.1980. Principles and procedures of statistics. MccGrawHill, Inc., London, U.K.

Twibell, R.G. and P.B. Brown, 1998. Optimal dietary protein concentration for hybrid tilapia Orechromis nilotica $X$ $O$. aureus fed all-plant diets. Journal of the World Aquaculture Society 29, 916.

Wafa, M.A. 2002. Nutrient requirements of Nile tilapia. Ph.D. Thesis, faculty Agriculture of Moshtohor, Zagazig University.

Watanabe, W.O.; Ellis,S.C. and Claves, J. 2001. Effects of lipid and energy to protein utilization of juvenile mutton snapper (Lutjanus anatis) fed isonitrogenous diets and two temperatures. Journal of the World Aquaculture Society 32. 30-40.

Yi,Y.; Clin, K. and Diana, J.S. 2002. Semi intensive culture of red tilapia in brackishwater ponds. PD/A CRSP Nineteenth Annual Technical Report In: K. McElwee, K. Lewis, M. Nidiffer, and P. Buitrago (Editors), Nineteenth Annual Technical Report. Pond Dynamics/Aquaculture CRSP. State University, Corvallis, Oregon. 